\title{
KAJIAN SKETSA DIGITAL DALAM PROSES REKA-STRUKTUR BENTUK-BENTUK SURFACE
}

\author{
Riva Tomasowa \\ Architecture Department, Faculty of Engineering, Binus University \\ Jalan K.H. Syahdan No. 9, Palmerah, Jakarta Barat 11480 \\ rivatomasowa@binus.ac.id
}

\begin{abstract}
Free form surface has a multiple complexity curve intrinsically, so that special approach is needed to form the structure. Geodesic shell is well-known as the shortest path between two points on a curved surface. This method is used to generate the structure of form, which can be easily determined by its basic shape or the complex form. This paper explains how Geodesic theory can assist to generate structures in the early stage of digital sketching. A workshop that has initially started becomes a topic to this discussion. The digital sketching process to apply the theory is the aim of this paper.
\end{abstract}

Keywords: Free form, surface, geodesic, digital sketch.

\begin{abstract}
ABSTRAK
Free form surface memiliki tingkat kesulitan bentuk kurva yang kompleks, sehingga perlu pendekatan khusus untuk mereka strukturnya. Geodesic dikenal sebagai garis kurva terpendek dari dua titik yang berseberangan pada suatu permukaan. Metoda Geodesic ini digunakan dalam mereka bentuk, baik yang mudah dikenali dari bentuk dasarnya atau yang kompleks. Tulisan ini membahas bagaimana teori Geodesic tersebut dapat membantu mereka bentuk bagi perancangan pada tahap awal sketsa digital. Sebuah loka karya yang telah mendahului tulisan ini, menjadi bahan dalam pembahasan dalam proses perancangan reka-struktur. Penerapanya pada proses sketsa digital menjadi kajian utama pembahasan.
\end{abstract}

Kata kunci: free form, surface, geodesic, sketsa digital 


\section{PENDAHULUAN}

Dengan logika geodesic, pendekatan perekaan struktur dapat dilakukan pada bentuk permukaan bebas (free form surface). Geodesic yang dikenal sebagai garis kurva terpendek dari dua titik yang berseberangan pada suatu permukaan lengkung, dapat digunakan dalam mereka-bentuk, baik yang mudah dikenali dari bentuk dasarnya atau yang kompleks menjadi rasional (Girling, 1957) dan shell adalah sebuah bentuk struktur 3D yang tips dan kaku yang terlingkupi oleh volume yang terikat oleh permukaan lengkung (Schodek \& Bechthold, 2008).

Pada tahap proses perancangan awal, perancang memetakan kunci-kunci usulan pemecahan masalah, dengan cepat dan spontan melalui sketsa (Szalapaj, 2005), begitu juga pengembangan bentuk dan logika strukturnya, terintegrasi dalam upaya visualisasi ini. Dalam prosesnya, arsitek atau perancang sukar sekali mereka struktur dari bentuk yang divisualisasikannya. Hal ini dikarenakan oleh latar belakang pengetahuan struktur atau karena kompleksitas bentuk yang terjadi. Pada bentuk bebas (free form) yang berkembang saat ini, bentuk-bentuk kurva dan permukaan lengkung (surface) menjadi tren dan memiliki daya tarik tersendiri. Selain telah didukung oleh kecanggihan konstruksi struktur, eksplorasi bentuk oleh aplikasi digital sangat dimudahkan.

Tulisan ini berupaya untuk: (1) memberikan gambaran tentang logika pemodelan yang mudah dengan menggunakan alat bantu digital dalam merasionalkan bentuk kedalam kerangka struktur; dan (2) memberikan contoh dari ekstensifikasi penelitian Geometry of Structural Frame (Lachauer \& Kotnik, 2010).

\section{METODE}

Melalui sebuah lokakarya terpadu, peserta yang adalah perancang diberikan penugasan untuk merancang sebuah bentukan, surface. Kemudian, sketsa surface tersebut diberikan pemetaan struktur pembentuknya. Dalam skema ini dimensi struktur dan kebenarannya masih diabaikan dan hanya berupa sketsa yang bertujuan sebagai perekaan bentuk dan ruang yang terjadi. Sebagai tahap awal penugasan, perekaan-bentuk menggunakan objek-objek bentuk-bentuk dasar cangkang (shell), untuk memberikan gambaran. Sketsa digital ini diharapkan memberikan pemahaman dan logika struktur sebagai dasar perekaan-bentuk yang lebih kompleks. Sketsa lanjutan adalah sketsa digital bentuk surface. Pada bentuk-bentuk inilah akan dikaji reka-strukturnya, membentuk reticulated structures. Sketsa digital pada lokakarya menggunakan aplikasi Rhino $3 D$ sebagai alat bantu perancangan dan pemrograman Grasshoper sebagai pengolah parameter.

\section{HASIL DAN PEMBAHASAN}

Berbagai bentuk surface dapat diciptakan oleh logika matematika yang terdapat pada aplikasi CAAD. Pada kajian kali ini, kategori surface yang diaplikasikan dibatasi pada ruled surface dan saddle surface (Hemmerling \& Tiggemann, 2011). Bentuk-bentuk surface ini dapat diterapkan sebagai pelat lantai, penutup atap, panel dinding atau kombinasi ketiganya sinambung. Setuju dengan pendapat Lachauer \& Kotnik (2010), Software CAAD 3D saat ini sudah mampu membentuk hubungan geometri seperti ini, sehingga hal ini tidak terbatas oleh teknik komputasi atau paket software. 
Dalam perekaan struktur tahap awal ini memang ada baiknya apabila keterbatasan kemampuan struktur sudah diperhitungkan (Lachauer \& Kotnik, 2010) agar tidak terjadi penurunan stabilitas dan kegunaan dari model di proses kedepan. Akan tetapi, meneruskan penelitian yang dilakukannya, optimasi bentuk struktur dapat dilakukan dalam fase perancangan lanjutanya, sehingga tidak mematikan kreatifitas awal dari visualisasi sketsa digital ini.

Eksplorasi free form surface, yang merupakan ekspresi bentuk bentang besar, identik dengan pelimpahan beban dua-arah, untuk menjaga kekakuannya. Berangkat dari sini, perekaan bentuk free form surface akan menggunakan logika dari Geodesi, yang membentuk kekakuan dengan konstruksi saling silangnya. Kemudian grid-grid struktur ditentukan disepanjang keliling dari surface. Dari titiktitik yang terpetakan itulah, ditarik garis-garis lurus, yang merupakan garis terdekat. Pola-pola grid ini bisa bermacam-macam dari segi bentang dan iramanya, di mana kreatifitas bisa terlibat di sini. Irama ini akan berekspresi memperkuat kesan dari bentuk surface. Hal ini memberikan nilai tersendiri yang memperkuat interpretasi bentuk. Contoh pengejawantahan free form surface menjadi reticulated structures dapat dilihat pada Gambar 1. Dalam kumpulan karya, Seminar "analog-digital" - Digital Manufacturing in Design and Architecture (Agkathidis, 2010), bentukan seperti diatas dinamai cross segmentation.

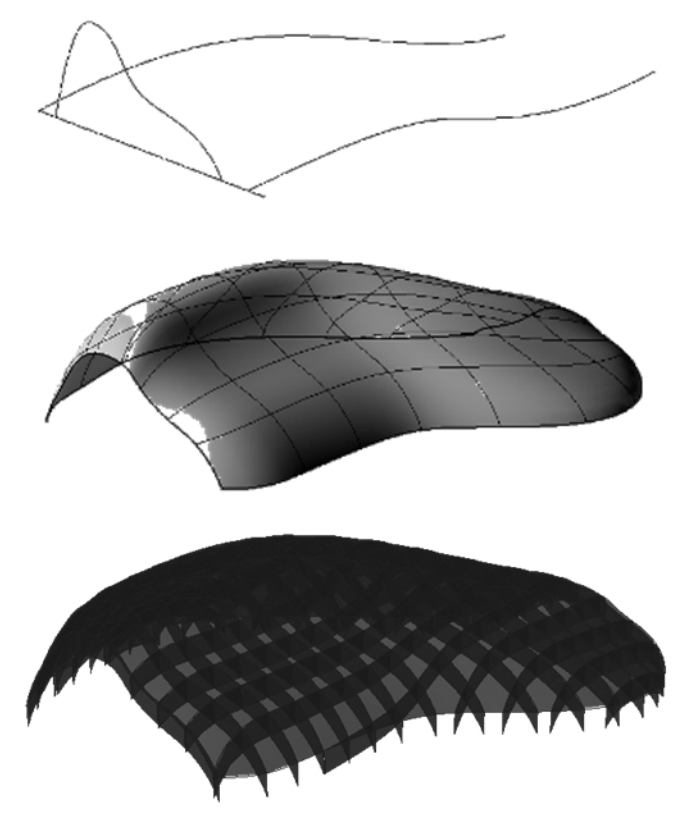

Gambar 1 Pengejawantahan free form surface menjadi reticulated structures

Peta grid tadi kemudian diproyeksikan ke obyek surface. Proyeksi tersebut memberikan lintasan reka-struktur dengan garis-garis Geodesic. Dalam memperkuat ekspresi kestrukturannya, garsi-garis Geodesic tersebut membutuhkan ketebalan struktur, dengan catatan dalam lokakarya ini, kebenaran dimensi struktur diabaikan, dan hanya mengandalkan proporsi visualisasi. Namun, dalam usaha pemodelan ketinggian struktur, Schodek (Schodek \& Bechthold, 2008) memberikan beberapa ilustrasi perhitungan tentang berbagai macam struktur. Kajian tersebut dapat melandasi logika penebalan struktur yang digunakan.

Dalam usaha reka-struktur kali ini dilakukan pendekatan dengan dua cara dalam komputasi untuk mendefinisikan ketebalan struktur (Gambar 2): (1) melalui surface offset; (2) salin-geser surface. Kedua pendekatan ini adalah usaha rasionalisasi dari bentuk kurva kompleks yang ada pada free form surface. 


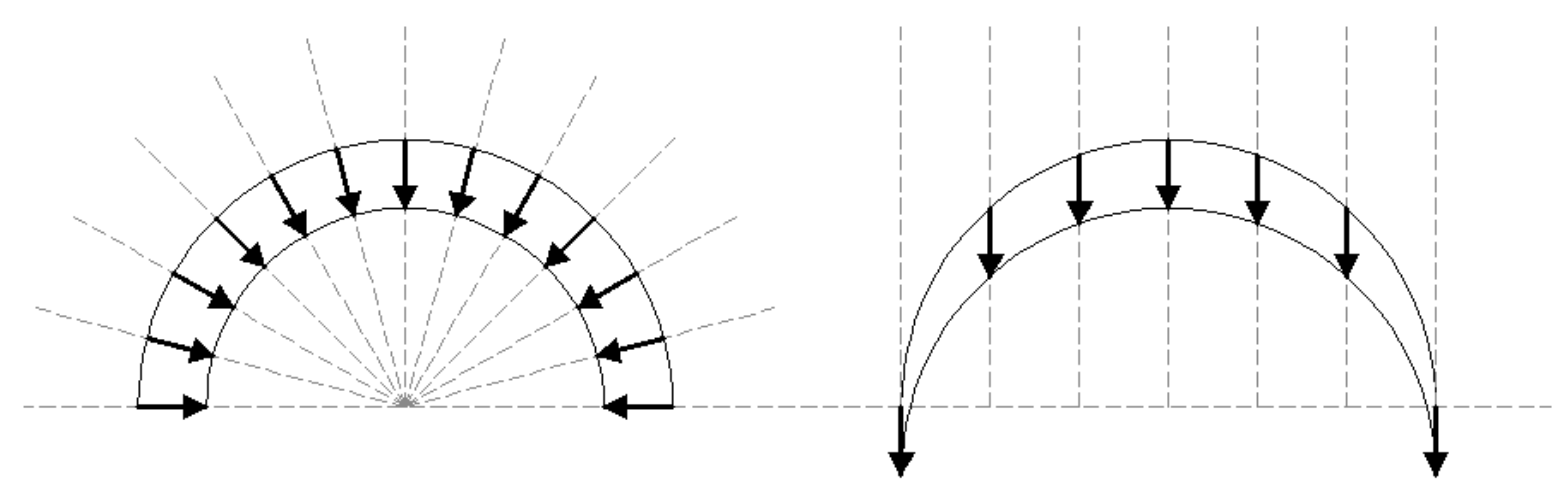

Gambar 2 a. Surface offset ke arah dalam; b. Surface yang disalin ke arah bawah

\section{Kasus 1: Surface Offset}

Pada kasus pertama, usaha pemberian ketebalan struktur dilakukan dengan surface offset: penebalan secara paralel terhadap permukaan dengan jarak yang konstan dari permukaan awal (Hemmerling \& Tiggemann, 2011). Ketebalan struktur yang direka bersifat seragam di semua titik, sehingga ketebalan ini mempengaruhi ruang efektif dibawah naungan surface-nya. Dampak dari ketebalan strukturnya ini memperkecil luasan denah dan tinggi langit-langit. Tetapi dengan irama yang berulang dan ketinggian yang konstan, ekspresi surface dari luar tercermin bentukannya hingga ke ruang dalam. Sehingga bentuk yang disketsa harus memperhatikan kebutuhan ruang di bawahnya.

\section{Kasus 2: Salin-Geser Surface}

Dalam proses pembentukan ketebalan struktur ini, ruang yang terbentuk di bawah naungannya tidak terlalu signifikan berkurang, karena bentuk kaki struktur yang ramping. Semakin tegak kurva geodesinya, semakin tajam pula kaki-kaki yang terbentuk. Proses kalkulasinya pun terhitung lebih ringan karena arah kurva mudah diatur, dengan definisi gerak: salin dan geser ke bawah. Sehingga, pembentukan ketebalan struktur, sangat minimal sekali proses surface menjadi terbalik atau terlipat (flip). Akan tetapi, bentuk ini terjadi pergeseran titik tumpu, tertanam terbawah, sehingga perlu ada rektifikasi bentuk bagian kaki dalam proses sketsa selanjutnya. Kelemahannya juga terjadi pada segmen-segmen kurva bagian kaki, yang melengkung ke arah dalam. Hal tersebut menyebabkan singgungan surface luar dan surface salinannya, sehingga tidak ketebalan struktur tidak rasional. Hasil proses reka-struktur salin-geser garis geodesi dapat dilihat pada Gambar 3.

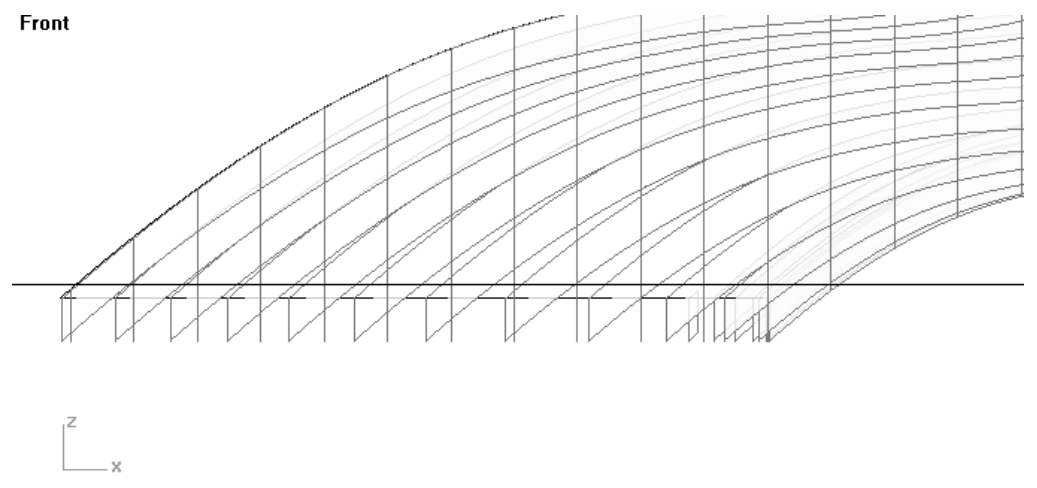

Gambar 3 Hasil dari proses reka-struktur salin-geser garis geodesi 


\section{PENUTUP}

Dalam proses reka ini terdapat beberapa masalah yang cukup menarik, di antaranya adalah: secara visual bentuk terlihat baik tetapi dalam kerangka operasi matematika yang dikomputasikan tidak benar; yang lain adalah secara komputasi bentuk yang terjadi adalah benar, namun secara visual, bentuk tidak logis. Schodeck menggambarkan bahwa free form shapes dalam komputasi dapat dibentuk dengan kurva multi-kompleksitas yang sukar untuk dikarakteristikan karena arah kurva yang kompleks (Schodek \& Bechthold, 2008). Ia menambahkan juga, bahwa bukan berarti hal ini harus dihindari, hanya saja secara logis struktur tersebut kurang efisien.

Namun demikian reka-struktur dengan pendekatan ini, rasionalisasi surface menjadi lebih mudah diaplikasikan. Kelogisan struktur secara visual dapat direka hingga tidak terjadi lipatan-lipatan pada gerenasi ketebalan struktur, disinilah usaha pencaharian bentuk yang memungkinkan. Selain itu, dalam proses dan pengembangannya, jalur kreatifitas akan mendukung dalam mengekspresikan struktur menjadi elemen arsitektur yang menarik. Langkah pengembangan berikutnya, dapat menelaah tentang kajian tipe struktur dan pembebanannya, sehingga terintegrasi dari tahap sketsa awal.

\section{DAFTAR PUSTAKA}

Agkathidis, A. (2010). Digital Manufacturing in Design and Architecture. Singapore: Page One Publishing.

Girling, P. R. (1957, April). Geodesic Shells. Vancouver: University of British Columbia.

Hemmerling, M., \& Tiggemann, A. (2011). Digital Design Manual. Berlin: DOM Publisher.

Lachauer, L., \& Kotnik, T. (2010). Geometry of structural form. Advances in Architectural Geometry (pp. 193-240). Vienna: Springer-Verlag.

Schodek, D. L., \& Bechthold, M. (2008). Structures (6th ed.). Englewood Cliffs: Prentice Hall.

Szalapaj, P. (2005). Contemmporary Architecture; and the Digital Design Process. London: Elsevier. 